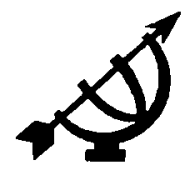

\title{
The legal duty of local government to facilitate development
}

Theo Scheepers

Department of Legal Pluralism and Legal History

Potchefstroom University for CHE

POTCHEFSTROOM

E-mail: rmrtes@puknet puk.ac.za

\begin{abstract}
The legal duty of local government to facilitate development

Local government in South Africa is not only facing challenges normally associated with a process of development or transformation, but needs to adjust its focus according to the new development paradigm unfolding in South Africa. Developmental local government has to accomplish this task according to the mandate issued in the Constitution and within a specific legal-institutional and value framework. The legal-institutional framework is based on a set of development law principles contained in new generation legislation. The value framework consists of community values as well as constitutional values reflecting individual and community values, norms and principles. This framework imposes a legal and moral duty as well as corresponding obligations on municipalities to plan and implement future socio-economic development of the areas for which they are responsible according to a new set of development principles and values. These principles make it incumbent upon municipalities to manage development through a people-centred and community-driven process. This article briefly deals with the nature and content of the duties and responsibilities of municipalities emanating from a new development paradigm when facilitating the development process within their areas of jurisdiction.
\end{abstract}

\section{Introduction}

The face, nature and functions of local government have, since the introduction of the Local Government Transition Act, and especially since the first democratic local government elections, changed drastically. One of the areas in which much change has occurred, is in the area of development and the duty to ensure that development policy and laws are implemented. Local government bodies, be they metropolitan, district or local municipalities, have a very specific 
responsibility towards the rural and urban communities they serve, a responsibility which now seems, within the context of the Constitution of the Republic of South Africa (specifically Chapter 7 dealing with Local Government) and the White Paper on Local Government, to include, at least, a legal duty to develop.

The duty to develop arises from the nature and scope of the development functions and responsibilities of local government bodies. These are clearly defined in the Constitution (section 153 read with the other sections of chapter 7), in the Development Facilitation Act, and in the internationally accepted Local Agenda 21, which have been accepted as part of the development framework applicable to South Africa.

This article will briefly consider the nature and contents of the duty imposed by law and policy on local government to ensure that development law and policies are implemented according to national and international development principles and standards.

\section{The constitution of the Republic of South Africa}

According to section 151 of the Constitution, the local sphere of government is made up by municipalities which cover the whole territory of South Africa, each with its own municipal council governing the affairs of its community on own initiative, subject to national as well as provincial legislation and the relevant provisions of the Constitution. The Local Government: Municipal Structures Act, 117 of 1998, read with the Local Government: Municipal Demarcation Act, 27 of 1998 (especially sections 24 and 25) further explain and define the scope and nature of the development functions and expected outcomes of these activities, at the level of government closest to the people. Each municipality must, within the limits of prevailing resource constraints strive to achieve the following general objectives (according to section 152 of the Constitution):

a) to provide democratic and accountable government for local communities;

b) to ensure the provision of services to communities in a sustainable manner;

c) to promote social and economic development;

d) to promote a safe and healthy environment; and

e) to encourage the involvement of communities and community organisations in the matters of local government.

Section 153 of the Constitution states, with regard to the development duties of municipalities, that every municipality must:

a) structure and manage its administration, budgeting and planning processes to give priority to the basic needs of the community, and to promote the social and economic development of the community; and 
b) participate in national and provincial development programmes

The duty to develop as envisaged in the Constitution should enjoy priority when managing the administration and budgets of a local authority. Not only should officials and councillors focus on basic needs of the community but they must also actively promote the social and economic development of that community It is part and parcel of the development duty of municipalities to participate in national and provincial development programmes, such as RDP and public works development projects. This duty is superimposed onto the list of functions of local government which includes, according to section 156 of the Constitution (read with part B of schedules 4 and 5) local government tasks and responsibilities relating to air pollution, building regulations, child-care facilities, electricity, fire fighting, tourism, airports, planning, public transport and public works. Local government is tasked with these responsibilities only in view of the needs of municipalities to administer functions specifically assigned to them under the Constitution or any other law. Other functions of municipalities are those pertaining to jetties, piers and harbours, storm-water management systems in built-up areas, trading regulations, water and sanitation services (limited to potable water supply systems and domestic waste-water and sewerage disposal systems, beaches, amusement facilities, billboards, cemeteries, control of public nuisances, control of enterprises that sell liquor to the public, the care and burial of animals, fencing and fences, dog licensing, licensing and control of undertakings that sell food to the public, local amenities, local sports facilities, markets, abattoirs, parks, recreation, roads, noise pollution, pounds, refuse removal, refuse dumps, solid waste disposal, street trading, street lighting, traffic and parking.

The functions of municipalities, listed above, serve as a delimitation of the areas of local and community life with regard to which municipalities have to exercise their legal duty to develop and to facilitate development.

The meaning of these provisions of the Constitution, and the manner in which they are to be given practical effect, in every-day life at the local sphere of government, become clear when these provisions are considered in the light of the White Paper on Local Government, development principles, now elevated to the level of development law, as well as internationally accepted development principles applicable to local government in South Africa.

\section{The White paper on Local Government}

The White Paper on Local Government, containing official policy on local government in South Africa, is based on the constitutional mandate (section 153 of the Constitution) for local government and places an obligation on local government to promote the Bill of Rights, the values of human dignity, equality and freedom, and to uphold the principles enshrined in the Constitution. Within 
the framework of the Constitution, the White Paper establishes the basis for a new developmental local government system. This system will bring about a local government which is committed to working with individuals, groups and communities and is committed to creating sustainable human settlements which provide for a decent quality of life and which meets the social, economic and material needs of those communities in a holistic way (wording and formulation taken from the White Paper, 1998).

According to the White Paper, the four inter-related characteristics of developmental local government, are:

- Maximising social development and economic growth.

- Integrating and co-ordinating.

- Democratising development.

- Leading and learning

The corresponding key outcomes to be achieved by local government, are:

- Provision of household infrastructure and services.

- Creation of liveable integrated cities, towns and rural areas.

- Local economic development.

- Community empowerment and redistribution.

According to the White Paper, environmental sustainability is a key challenge in both urban and rural settlements. Environmental issues and considerations are therefore to be included in the land development objectives and integrated development plans to be prepared by municipalities and district councils. Specific reference is made in this policy document to the requirements of Local Agenda 21 , namely that municipalities have to develop strategic plans for dealing with sustainable development. It is noted in this policy document that the concept of sustainable development also embraces the idea of environmental sustainability as an integral part of the process of designing long-term integrated development plans.

The Development Facilitation Act (DFA), which came into operation on 22 December 1995, lays down inter alia general principles of national application for land development at local, and other levels of government. These principles are clearly aimed at facilitating the formulation and implementation of land development objectives to be contained in policy, law and administrative action. The DFA specifically provides for the performance of local government bodies in achieving predetermined development objectives to be measured with reference to the general development principles listed in section 3 of the DFA

For a proper understanding of the value and meaning of the land development principles contained in the DFA, the sections dealing with development 
principles should be read and understood with reference to those development principles internationally accepted as part of the duties and functions of local government bodies or municipalities, as formulated in the Local Agenda 21 strategic programme.

\section{Local Agenda 21}

In 1992 a large conference on Environment and Development was organised by the United Nations in Rio de Janeiro in Brazil. World leaders and representatives attending the conference, signed a declaration which incorporated a number of principles forming the basis for future development policy (UNCED, 1992). South Africa did not officially participate, but did attend through representatives who made it clear to the conference that South Africa supports and subscribes to the declaration as agreed to at the end of the conference. One of the documents adopted at the plenary meeting was Agenda 21, a blueprint on how to make development socially, economically and environmentally sustainable, as nations and communities move into the next century (Lutsch, n.d.). One of the objectives of Agenda 21 is to ensure that each local authority has drawn up its own Local Agenda by 1996 in close consultation with its citizens. It is one of the prerequisites of Agenda 21 that the principle of sustainable development must form part and parcel of each Local Agenda. Of the 2500 action items of Agenda 21 , two thirds relate to municipalities functioning as local government organisations. The role of municipalities as the administrative tier of government closest to the citizens, is recognised as being of crucial importance in implementing environmental and development policies and this accordingly also applies to the laws that flow from these policies. The prominent position conferred on municipalities by Agenda 21 places a specific responsibility and duty on local government to see to it that development policy and plans are formulated and implemented according to international standards included in Agenda 21 and Local Agenda 21 programmes.

Local Agenda 21 (LA 21) originates from chapter 28 of the Agenda 21 document accepted at the Rio Summit on Environment and Development, referred to above. Local Agenda 21 programmes are at present being implemented in many different countries all over the world. In South Africa, Durban was the first city to formally respond to the Local Agenda 21 challenge (Roberts, 1995). Johannesburg and Cape Town followed soon, while other cities are in the process of doing the same.

Based on Agenda 21 principles, a Local Agenda 21 is an agenda compiled by a local government body, referred to in the Agenda 21 document as a municipality, on how to achieve consensus among all sectors of the community about setting up and implementing a long-term action plan towards sustainability. Such a LA 21 consensus plan will describe visions, goals, targets, instruments, proposed actions, evaluation criteria and methods. At the same time 
the LA 21 represents a participatory process involving all sectors of the local community. It is part of a process aimed at encouraging a democratic and participatory decision-making process and an inclusive and open approach to managing development in terms of an action plan for sustainability in partnership with all role players concerned.

\section{Development law aspects of Agenda 21}

The Agenda 21 document of the Rio Summit is divided into a preamble (chapter 1) and 4 sections, each section respectively dealing with one of the following aspects of integrated sustainable development:

- Social and economic dimensions (chapters 2-8).

- Conservation and management of resources (chapters 9-22).

- Strengthening the role of major groups (chapters 23-32).

- Means of implementation (chapters 33-40).

Chapter 8, under the heading "Integrating Environment and Development in Decision-Making", emphasises the point that it is necessary to understand the links between environment and development in order to make development choices that will be economically efficient, socially equitable and responsible, as well as environmentally sound. This chapter is devoted to the following programme areas (Lutsch, n.d.):

- Integrating environment and development at policy, planning and management levels.

- Providing an effective legal and regulatory framework.

- Making effective use of market, economic and other instruments.

- Establishing systems for integrated environmental and economic ccounting.

On the issue of development law it is further pointed out in Chapter 8 that much environmental and development law making seems to be ad hoc and piecemeal and often lacks enforcement or updating (Lutsch, n.d.). The document further stresses the need for governments to foster the evolution of sustainable development law, based on sound economic, social and environmental principles and appropriate risk assessment, backed up by effective enforcement.

Chapter 10, in dealing with an "Integrated Approach to the Planning and Management of Land Resources", prescribes that governments should take into account social, economic and environmental issues when drafting laws, regulations and economic incentives to encourage sustainable use and management of land resources (Lutsch, n.d.). Chapter 23 emphasises the need for the dissemination of all information relevant to the environment and the impact of development on the environment. Such data are required by 
communities, their leaders and community-based organisations in order to make informed and effective development decisions.

Viewed from a development law perspective, any LA 21 will require, as part of the anticipated development management process at local level, a suitably designed legal framework of appropriate by-laws to support the development process according to these principles.

The main thrust of Chapter 28 is, however, directed at the important role local authorities will have to play in making sustainable development happen (Lutsch, n.d ). Being the level of government closest to the people, they play a vital role in educating and mobilising the public around an agenda for sustainable development. As part of an inclusive strategy, local authority officials and leaders should consult citizens, the community, business and industry in order to build consensus on clear and well defined, sustainable strategies for the future.

While LA 21 is strictly not legally binding in the same manner as a law of parliament or the provincial legislature, it is of great importance to local government in South Africa. It reflects the consensus of 178 national delegations on issues of principles, based on the value of sustainability as a core value on the basis of which to deal with the key issues that must be addressed by municipalities in order to successfully achieve their development goals and objectives. The willingness and ability of South Africa to enter the international arena on terms and conditions prescribed by and for international participants, as well as the need to conform with international standards in order to qualify for financial aid and investment from abroad, are all factors which render it impossible for local government institutions in South Africa to ignore LA 21 values and principles of development.

\section{Local government and sustainable development}

In order to fully understand the nature and scope of development duties and the responsibilities of local government, as set out in the DFA and other development laws, the terms local government and sustainable development have to be understood within the context of policy and legal thinking of today.

\subsection{Local government}

The Development Facilitation Act applies to all local government bodies and the areas in respect of which they execute local government functions. Section 1(xviii) of the DFA defines a local government area as the area of jurisdiction of a local government body in terms of any law. In section l(xix) a local government body is defined as any institution or body referred to in legislation on provincial government, including: 


\section{The legal duty of local government to foclittote development}

- any local government body established in the areas formerly known as the TBVC States ${ }^{1}$ or as Black Local Authorities;

- a body referred to in section 84(1)(f) of the Provincial Government Act;

- a body established under the Black Administration Act; ${ }^{3}$ or

- any body continuing to perform local government functions by virtue of section 15(1) of the Local Government Transition Act.

For purposes of the DFA, a local government also includes management boards ${ }^{4}$, a local government committee 5 , a local council6, a Local Government Affairs Council ${ }^{7}$, any regional services council ${ }^{8}$, any joint services board ${ }^{9}$, any joint decision-making body, joint local authority or single local authority ${ }^{10}$ as well as any person, institution or body declared to be a local government body11. Those transitional bodies established for the interim phase of local government transformation ${ }^{12}$ are included as municipalities established or to be established under the 1998 municipal structures legislation and for local government areas of jurisdiction demarcated in accordance with the municipal demarcation law and procedures (mentioned above) as local government areas to which the DFA,

1 By or under any law which, in terms of section 229 of the Constitution, continues to be in force in the former Republics of Transkei, Bophuthatswana, Venda or Ciskei

2 As any council or committee established under the provisions of the Black Local Authorities Act, 102 of 1982, prior to the repeal of that Act by section 13 of the Local Government Transition Act, 209 of 1993

3 Section 30(1)(a) of the Black Administration Act, 38 of 1927

4 Being a board of management or board referred to in section 1 of the Rural Areas (House of Representatives) Act, 9 of 1987

5 Being any committee referred to in section 17 of the Promotion of Local Government Affairs Act, 91 of 1983 .

6 Being any local council established under section 2 of the Local Councils (House of Assembly) Act, 94 of 1987.

7 Established by section 2 of the Local Government Affairs Council (House of Assembly) Act, 84 of 1989.

8 Established under section 3 of the Regional Services Councils Act, 109 of 1985.

9 Established under section 4 of the KwaZulu and Natal Joint Services Act, 84 of 1990

10 Referred to in paragraphs (c), (e) and (f) of section 8 of the Interim Measures for Local Govermment Act, 128 of 1991, and established by proclamation issued under that Act.

11 Under section 1(2) of the Local Government Transition Act, for the purposes of that Act.

12 Under the Local Government Transition Act, which exercises local government functions to the exclusion of any of the aforementioned local government bodies. 
and other development law applies. Local government, in the form of metropolitan, district and local municipalities of various types and categories, are restructured and transformed entities operating at the local sphere of government in newly demarcated areas of jurisdiction.

\subsection{Sustainable development}

The concept of sustainable development is a much debated attempt to define how to proceed with development, especially economic expansion, without destroying natural systems and community life, both of these making life for ordinary citizens possible and worthwhile. Sustainable development extends to the development industry the challenge to manage development in such a way that the best use is made of talents and resources of local communities, while the management process must be supportive of community life and initiatives emanating from the community (Scheepers, 1995), as well as committed to distribute the benefits of development equitably so as to sustain these benefits in the long term (ICLEI, 1997).

At local level, traditionally, the products of development are services. These services firstly affect the environment, e.g. water, waste management, land, vegetation and the atmosphere. Secondly there are economic services, such as transportation and infrastructure, to name but a few. Thirdly, social services account for such other services as health and education. Sustainable development at local government level calls for a unique approach engaging municipalities and local residents, as well as community leaders and cultural organisations, in the design and delivery of these services. Community values, be they cultural or religious, form part of community goals and aspirations. In delivering these services role players must also take care to uphold values aimed at protecting local, regional and global ecosystems. The successful achievement of human, environmental and economic sustainability depends on achieving harmony between the legal-institutional principles and the values of communities and individuals.

\section{Development principles contained in the DFA}

\subsection{Application of development principles of the DFA}

According to section 3 of the DFA, general principles for land development shall:

- apply throughout the Republic and also apply to actions of the state and every local government body; 
- serve to guide the administration of any physical plan, transport plan, guide plan, structure plan, zoning scheme or similar plan or scheme administered by that authority in terms of any law;

- serve as guidelines by reference to which any competent authority shall exercise any discretion or take any decision, in terms of a law, dealing with land development, including a law dealing with the subdivision, use and planning of land.

The DFA provides development managers throughout South Africa with a uniform code of development principles. These principles are to be applied in the land administration process when taking development decisions and when implementing development plans. For the first time in history role players in the development process in South Africa function within a single development law (and institutional) framework applicable to all development.

For the purposes of Chapter IV (sections 27 to 29 of the DFA), dealing with the planning and implementation of development objectives for local government areas, the prescribed land development principles serve as a set of guidelines with reference to which the formulation, implementation as well as the carrying out of land development objectives by local government bodies, shall be assessed.

The necessity for local (and other) authorities to adhere to these principles when planning for development and when implementing development policy, or simply when exercising their normal day to day duties in the interest of the development of the areas or communities concerned, arises directly from the DFA and is not merely a matter of choice or a matter of doing so for the sake of political expediency. In line with modern international development law there are no specific clauses contained in the DFA providing for penalties and offences resulting from non-performance or non-compliance with the development guidelines contained in the Act. It is, however, unlikely that a local government council, refusing to proceed with development in the manner provided for by the Act, will be re-elected. The possibility exists that failure to conform to development objectives or to apply the prescribed land development principles, will result in severe cuts in budget allocations made by provincial or central government in respect of capital project expenditure of the local authority in question. Action can be taken against any official of (local) government refusing or failing to exercise his or her duties in terms of the provisions of the DFA

\subsection{The land development principles contained in the DFA}

The land development principles of the DFA can be summarised as follows: 
- The principle of unformity and equal treatment: Land development principles (contained in section 3 of the DFA), apply to all land development policy, administrative practice and laws for urban and rural land development and should facilitate the development of formal and informal, existing and new settlements.

- The principle of legitimate land use: Policy, administrative practices and laws should discourage the illegal occupation of land, with due recognition of informal land development processes.

- The principle of accommodating the interdependence of available resources in a holistic approach to harmoniously managing human, natural and financial resources: Policy, administrative practice and laws should promote efficient and integrated land development in that they

- promote the integration of the social, economic, institutional and physical aspects of land development;

- promote integrated land development in rural and urban areas in support of each other;

- promote the availability of residential and employment opportunities in close proximity to or integrated with one another;

- optimise the use of existing resources including resources relating to agriculture, land, minerals, bulk infrastructure, roads, transportation and social facilities;

- promote a diverse combination of land uses, also at the level of individual erven or subdivisions of land;

- discourage the phenomenon of "urban sprawl" in urban areas and contribute to the development of more compact towns and cities;

- contribute to the correction of the historically distorted spatial patterns of settlement in the Republic and to the optimum use of existing infrastructure in excess of needs,

- encourage environmentally sustainable land development practices and processes

- The principle of community-based and community-driven development: Members of communities affected by land development should actively participate in the process of land development, while the skills and capacities of disadvantaged persons involved in land development should be developed.

- The principle of partnership between all sectors: Policy, administrative practice and laws should encourage and optimise the contributions of all sectors of the economy, government and non-government to land develop- 
ment so as to maximise the Republic's capacity to undertake land development and (adhering to the principle of transparency) to this end, and without derogating from the generality of this principle,

- national, provincial and local governments should strive clearly to define and make known the required functions and responsibilities of all sectors of the economy in relation to land development as well as the desired relationship between such sectors, and

- a competent authority in national, provincial or local government responsible for the administration of any law relating to land development shall provide particulars of the identity of legislation administered by it, the posts and names of persons responsible for the administration of such legislation and the addresses and locality of the offices of such persons to any person who requires such information

- The principle of accountability: Laws, procedures and administrative practice relating to land development should (i) be clear and generally available to those likely to be affected thereby, (ii) in addition to serving as regulatory measures, also provide guidance and information to those affected thereby; (iii) be calculated to promote trust and acceptance on the part of those likely to be affected thereby; and (iv) give further content to the fundamental rights set out in the Constitution.

- The principle of development within the limits of resource constraints but in accordance with the needs and potential of communities: Policy, administrative practice and laws should promote sustainable land development at the required scale in that they should (i) promote land development which is within the fiscal, institutional and administrative means of the Republic, (ii) promote the establishment of viable communities; (iii) promote sustained protection of the environment; (iv) meet the basic needs of all citizens in an affordable way; and (v) ensure the safe utilisation of land by taking into consideration factors such as geological formations and hazardous undermined areas.

- The principle of quick and efficient development action: Policy, administrative practice and laws should promote speedy land development.

- The principle of bottom-up planning and design in accordance with the real needs and potentıal of each given case: Each proposed land development area should be judged on its own merits and no particular use of land, such as residential, commercial, conservation, industrial, community facility, mining, agricultural or public use, should in advance or in general be regarded as being less important or desirable than any other use of land 
- The principle of not prescribing land tenure rights but dealing with land use rights as found in various areas: Land development should result in security of tenure, provide for the widest possible range of tenure alternatives, including individual and communal tenure, and in cases where land development takes the form of upgrading an existing settlement, not deprive beneficial occupiers of homes or land or, where it is necessary for land or homes occupied by them to be utilised for other purposes, their interests in such land or homes should be reasonably accommodated in some other manner.

- The principle of appropriate community-based development management. A competent authority at national, provincial and local government level should co-ordinate the interests of the various sectors involved in or affected by land development so as to minimise conflicting demands on scarce resources.

- The free market development principle: Policy, administrative practice and laws relating to land development should stimulate the effective functioning of a land development market, based on open competition between suppliers of goods and services.

In terms of section 3(2) of the DFA the minister may by notice in the Government Gazette prescribe any principle for land development in addition to, but not inconsistent with, the principles set out in the Act. According to section $3(3)$, the premier of a province may also by proclamation in the Provincial Gazette prescribe any principle for land development in addition to, but not inconsistent with, the principles set out in the Act or prescribed by the minister

These principles are principles of development law based on values that are in line with values expressed in the Constitution and reflected in the principles contained in the internationally accepted Agenda 21 declaration, discussed above. The development principles constitute more than a mere legalinstitutional framework, but also reflects clearly defined values to be adhered in giving effect to the legal duty of municipalities to ensure that development takes place in accordance with their constitutional mandate.

\section{Principles for decision-making and conflict-resolution}

Section 4(1) and (2) of the DFA also prescribes, in addition to land development principles, general principles applicable to:

- any decision which a competent authority, including a tribunal, may make in respect of any application to allow land development;

- in respect of land development which affects the rights, obligations or freedoms of any person or body, whether the application is made, or the development undertaken in terms of this Act or in terms of any other law; 
- any decision on the question whether any (seemingly) illegal use of land should henceforth be regarded as lawful;

- any decision approving or disapproving of any proposed change to the use of land in the course of proposed land development;

- any decision relating to the level or standard of engineering services that are to be provided in respect of land development;

- any decision relating to the permitted periods within which comments or objections should be provided and governmental decisions are to be taken during the course of land development procedures;

- any decision relating to the consequences for any land development or for the rights and obligations of any person or body of a failure to provide any comment, make any decision or perform any other act within a period of time contemplated in the DFA;

- where a decision is made under any other law, only when such decision is made during the course of the administration of a law made after the commencement of the DFA by the legislature of a province or by a local government body, including a law which is inconsistent with the uniform principles and guidelines prescribed by the DFA, as summarised above.

These cases or circumstances, in which the general principles of decisionmaking and dispute-resolution should be applied, represent typical cases in the everyday life of an official in the employ of a local government body, actively involved in a development project of some kind. These circumstances call for responsible and informed decision-making at local government level.

The decisions taken in the circumstances mentioned above, shall (as per the DFA) be taken in accordance with the following general principles:

- The decisions shall be consistent with the principles of national policy set out in or prescribed in the DFA.

- The decisions shall be made by at least one appropriate official in the service of a provincial administration or local government body and by experts in the field of agriculture, planning, engineering, geology, mining, environmental management, law, survey or such other field as may be determined by the premier.

- The officer and experts shall, before conducting a hearing or reaching a decision, enquire into and consider the desirability of first referring any dispute between two or more parties in relation to land development to mediation, and if they (i) consider mediation appropriate, they shall refer the dispute to mediation; or if they (ii) consider mediation inappropriate, or if mediation has failed, the officer and experts shall conduct a hearing 
appropriate in the circumstances and reach a decision binding upon persons or bodies affected thereby, including the state or any local government body.

- The hearing conducted by the officer and experts is open to the public and any person entitled to appear at the hearing may be represented by any other person.

- The officer and experts shall upon request provide written reasons for any decision reached by them

- The director-general of a provincial administration shall keep a record of reasons so provided, make such record available for inspection by members of the public and permit the publication of such reasons by any person or body.

- A decision made by the officer and experts shall be subject to review by any division of the Supreme Court of South Africa having jurisdiction.

A municipality is a competent authority, within the meaning of section $4(1)$ of the DFA. When taking decisions on land development and in respect of developments which may affect the rights, obligations and freedoms of other people, the above guiding principles should dictate the manner in which municipalities deal with development decisions. Not only will this lead to uniform practice in the management of development projects, but it will also protect local decision-makers from having their decisions taken on appeal or review to be scrutinised in the light of the land development principles contained in the DFA.

\section{Local government and development planning}

Land development objectives, described in section 28 of the DFA, must be prepared by every municipality for its area of jurisdiction, to be approved by the MEC responsible for local government in that province. If a local government body fails to set land development objectives, either generally or in respect of any particular case, within a period of time prescribed by the MEC in the Provincial Gazette, the MEC may himself (herself) set land development objectives in respect of that local government area. The objectives set by the responsible MEC shall prevail over objectives subsequently set by that local government body. These land development objectives are to be set in the manner, within the time limits and after following the procedures prescribed by the MEC in the Provincial Gazette. The MEC prescribes procedures relating to:

- the manner in which members of the public and interested bodies shall be consulted in the setting of land development objectives; and

- the manner in which the setting of land development objectives shall be coordinated with the functions of any department of state or other authority responsible for the administration or formulation of any plan dealing with 
subject matter, which is the same as or similar to the subject matter set out in section 28.

It is interesting to note that the effect of the above-mentioned guidelines prescribed by the MEC revolves around the question of involving civil society and ensuring co-operative government in the development planning process. Municipalities must in their planning, which is done in the form of Ido's according to section 28(1) of the DFA, include the following:

- The development objectives of the municipality in relation to access to and the standard of services, including public transport, water, health and education facilities.

- The objectives (with reference to local circumstances, including demographic circumstances and prevailing spatial patterns) relating to urban and rural growth and form in the relevant area, including objectives in relation to the integration of areas settled by low-income communities into the relevant area as a whole, the sustained utilisation of the environment, the planning of transportation, the provision of bulk infrastructure for the purpose of land development, the overall density of settlements, with due regard to the interests of beneficial occupiers, the co-ordination of land development in consultation with other authorities, land-use control, the optimum utilisation of natural resources; and such other matters as the MEC may determine by notice in the Provincial Gazette.

- The development strategies of that municipality in relation to the facilitation of the optimal involvement of all sectors and sub-sectors involved in land development, access to finance for land development, available administrative or proposed new administrative structures to deal with land development in the relevant area, and also such other matters as the MEC may determine by notice in the Provincial Gazette.

- The quantum of development outputs in the sense of (i) the number of housing units, sites or other facilities planned for; (ii) whether such units, sites or other facilities will be delivered by means of upgrading land or built environments, undertaking new land developments or the letting of land or buildings; (iii) the rate at which the production or delivery of such units, sites or facilities will increase during a period in future, which period may be determined by the MEC in the Provincial Gazette; and (iv) the other matters determined by the MEC by notice in the Provincial Gazette.

It is of significance, especially in view of the LA 21 programmes referred to above, that a local government body or the MEC may require persons or bodies determined by him or her to carry out environmental evaluations in order to assess the likely impact of any land development objective upon the environment. 
The land development objectives and other plans, set by local government, has the effect that a tribunal or any other competent authority shall not approve a land development application in terms of the DFA or any other law dealing with the establishment of land development areas, if such application is inconsistent with any land development objective contemplated in the DFA. Should it happen that a land development objective set in terms of the DFA is expressly inconsistent or incompatible with any plan as defined in the Physical Planning Act, the land development objective shall prevail over the plan and the plan shall for the purposes of that Act be deemed to have been amended accordingly. It should also be noted that despite anything to the contrary contained in the Physical Planning Act, the MEC may, subject to the procedures deemed fit by him or her or that he or she may prescribe by notice in the Provincial Gazette, amend or withdraw, whether in whole or in part, a guide plan referred to in that Act.

The matters dealt with in the LDO planning process are mostly focused on infrastructure as a development priority defined in the Reconstruction and Development Programme, the official development policy of government. This planning process follows the mission statement defined by the municipality and the other stake holders as their joint vision of the future. Not only is planning therefore an exercise by local government and civil society as equal partners in the development process, but in addition value is added to the planning and development process at local level according to the values deeply embedded in the harts and minds of all communities living in a municipal area.

\section{Conclusion}

The duty of local government in South Africa is to ensure that development takes place and that this actually happens in accordance with Local Agenda 21, national and international development law principles and the values of people and communities concerned. The future performance of local authorities are measured against their development plans and objectives which they have set for themselves in close consultation with all role players in the areas for which they are responsible.

When considering the above duty to develop within the legal and value framework discussed above, it becomes alarmingly clear that much of our development laws, regulations and by-laws, dealing with development (especially at local government level) ought to be revised immediately. It is also important to note that such reform will demand that the procedures and strategies for implementing development policy and plans, should not only be supported by a democratic inclusive consultation process, but also by supportive legal (and development law) training of local councillors and staff operating at middle as well as at senior management levels of every municipality entrusted with the duty, mandate and task to develop the country and its people. 
The national and international principle framework, as reflected in modern day development laws in South Africa, calls for an open mind and heart when planning and implementing development principles, policies and plans - open in the sense of displaying a willingness to listen to and to understand the values of our multi-cultural society. There is no justification for ignoring religious, cultural and other values of the communities participating in and served by transformed municipal structures and systems designed to give effect to a new socio-political order in South Africa.

\section{References}

ICLEI

See INTERNATIONAL COUNCIL FOR LOCAL ENVIRONMENTAL INITIATIVES

INTERNATIONAL COUNCIL FOR LOCAL ENVIRONMENTAL INITIATIVES (ICLEI) 1997. Local Agenda 21 Handbook. Toronto : World Secretariat.

LUTSCH, W, n.d. Report of the United Nations Conference on Environment and Development Rio de Janeiro. Pretoria : Department of Environmental Affairs.

ROBERTS, D. 1995 Sustainable Reconstruction and Development: Durban's Local Agenda 21 Programme. Paper prepared for the Local Agenda 21 African Regional Seminar, Johannesburg, 10-11 April.

UNCED

See UNITED NATIONS CONFERENCE ON ENVIRONMENT AND DEVELOPMENT

UNITED NATIONS CONFERENCE ON ENVIRONMENT AND DEVELOPMENT (UNCED). 1992. Giving insight into the results of the Rio de Janeiro conference and describing local authority developments and the first results of these. Pretoria Department of Constitutional Affairs

MINISTRY FOR PROVINCIAL AFFAIRS AND CONSTITUTIONAL DEVELOPMENT 1998. White Paper on Local Government. Pretoria : CDP Book Publishers.

SCHEEPERS, T. 1995. The key to success - Understanding the real nature of the social compact Housing in Southern Africa, 29, July

\section{Legislation}

Black Administration Act, 38 of 1927.

Black Local Authorities Act, 102 of 1982.

Constitution of the Republic of South Africa, 108 of 1996

Development Facilitation Act, Act 67 of 1995. (DFA).

Interim Measures for Local Government Act, 128 of 1991

KwaZulu and Natal Joint Services Act, 84 of 1990.

Local Councils (House of Assembly) Act, 94 of 1987.

Local Government Affairs Council (House of Assembly) Act, 84 of 1989

Local Government: Municipal Demarcation Act, 27 of 1998

Local Government: Municipal Structures Act, 117 of 1998.

Local Government Transition Act, 209 of 1993

Physical Planning Act, 125 of 1991.

Promotion of Local Government Affairs Act, 91 of 1983

Provincial Government Act, 32 of 1961

Regional Services Councils Act, 109 of 1985

Rural Areas Act (House of Representatives), 9 of 1987 